\title{
Oktatói kompetenciák - ahogyan azt a hazai oktatók látják
}

\section{Kálmán Orsolya}

az Eötvös Loránd Tudományegyetem Pedagógiai és Pszichológiai Karának adjunktusa kalman.orsolya@ppk.elte.hu

A kutatás feltárja, hogy a hazai oktatók hogyan értelmezik az oktatási kompetenciákat, miben látják eredményesnek vagy kevésbé eredményesnek magukat, valamint hogy az oktatók értelmezései közt milyen különbségek mutathatók ki a képzési területek szerint és a tanítási tapasztalatok változásával. Eredményeink szerint a tanulásközpontú megközelités egyes elemei (például a hallgatók tanulásának támogatása) fontossá váltak az oktatók számára, s az ehhez a megközelitéshez szorosan kapcsolódó kompetenciák elsősorban a képzési területek mentén mutatnak eltérést, nem a tanítási tapasztalat növekedésével.

Kulcsszavak: oktatói kompetenciák, szakmai fejlődés és tanulás, felsőoktatás, képzési területek, tanitási tapasztalat

DOI: 10.37205/TEL-hun.2019.1-2.01

\section{Problémafelvetés}

A hazai felsőoktatási gyakorlatban az oktatók tanítási tevékenységéhez elsősorban még mennyiségi szempontok kötődnek - például, hogy egy oktató hány órát tart hetente -, de már látszik, hogy a hallgatók megnyerése és megtartása, a képzések eredményességének növelése érdekében erősödnek a tanítás minőségi szempontjai is. A tanítás minőségének, az oktatás eredményességének kérdései a felsőoktatásban összekapcsolódnak a tanuló- vagy tanulásközpontú megközelítéssel (vö. Hénard - Rosevaere, 2012), ami bár gyakran jelenik meg kitűzött célként olykor sajnos szlogenként -, nem vált általánosan elfogadott és közösen értelmezett gyakorlattá. Jelen kutatás ezért ahhoz kíván hozzájárulni, hogy jobban értsük, hogyan gondolkodnak a felsőoktatásban dolgozó oktatók a minőségi tanítás elemeiről és ezzel kapcsolatos felkészültségükről. A tanulmányban ehhez az oktatói kompetenciák értelmezésére és értékelésére fogunk építeni, ami a pedagógusok tanítása és szakmai tanulása kapcsán már régebbi irány (Falus, 2006), de a felsőoktatásban ennél kevésbé erős. 
A tanítás fejlesztése szempontjából kulcstényezőnek tartjuk az oktatókat, illetve hogy ők hogyan gondolkodnak a tanításról, szakmai felkészültségükről és saját tanulásukról, hiszen ennek ismerete elengedhetetlen a felsőoktatási fejlesztések, innovációk eredményessé válásához. Az oktatók szakmai felkészültségéről, kompetenciáiról eddig még nem született átfogó kutatás a hazai kontextusban, pedig a minőségi tanítás kultúrájának megerősödéséhez elengedhetetlen, hogy a diskurzus megalapozott kutatási eredményekre építsen. Ezért a hazai oktatók körében végzett kérdőíves kutatás ${ }^{1}$ az oktatók kompetenciákról alkotott elképzeléseit tárja fel, és azt is vizsgálja, hogy a felsőoktatás oktatói mennyire látják differenciáltan ezt a képzési területek és a tanítási tapasztalatok mentén. ${ }^{2}$

\section{Az oktatók elképzelései az oktatási kompetenciáik fontosságáról és észlelt eredményességéről}

E kutatás a hazai oktatók elképzeléseire fókuszál, és épít a hazai pedagógusok, pedagógusjelöltek nézetkutatásainak hagyományaira is (Falus, 2007; Kálmán, 2013). Az oktatói felkészültségről alkotott személyes, érzelmektől sem mentes, tudatos vagy nem tudatos, igaznak vélt vélekedések, azaz a nézetek olyan „szűrőkként” szolgálnak, amelyeken keresztül látjuk a felsőoktatásban való tanítás lehetőségeit, és ami irányítja azt is, hogy hogyan viselkedünk, tevékenykedünk a tanítás során (vö. Borg, 2001; Falus, 2006; Kálmán, 2009). Az oktatói kompetenciákról alkotott elképzelések az oktatói nézetvizsgálatoknak csak egy szeletét jelentik, ugyanakkor mindez fontos kiindulópontja lehet az oktatói szerep professzionalizálódásáról és az oktatók szakmai fejlődéséről, tanulásáról szóló diskurzusoknak; továbbá az észlelt kompetenciák egyfajta előrejelzői lehetnek az oktatási tevékenység eredményességének is, mivel a kompetenciaérzés meghatározó a tevékenység eredményessége szempontjából (Bandura, 1993; Koltói, 2017).

Az alábbiakban tehát az oktatói kompetenciák olyan értelmezési keretét igyekszünk kialakítani, amely épít a tanuló- és tanulásközpontú megközelítések kutatási eredményeire, valamint a hazai kontextus sajátosságaira is. A tanuló- és tanulásközpontú megközelités sokféle értelmezése, iránya kapcsán ebben a tanulmányban a következő szempontokat vettük figyelembe: a hallgatók aktív, konstruktív, értelmező tanulási folyamatát középpontba állító tanítás, ami a tanulástámogatást minden hallgatóra kiterjeszti és kimozdul a csak kurzus szintű támogatásból (vö.

\footnotetext{
${ }^{1}$ A kutatás a Bolyai János Ösztöndíj támogatásával készült.

${ }^{2}$ Az oktatói kompetenciákról alkotott elképzelések nem függetlenek az oktatók tanításról és saját tanulásukról alkotott elképzeléseitől, amelyek elemzését egy később megjelenő tanulmányban foglalom össze.
} 
Prosser és mtsai, 1994; Kember - Kwan, 2000; Rapos és mtsai, 2011; Kálmán, 2013b). A tanulás- és tanulóközpontú megközelítés összhangban áll a tanulási eredmények alapú tanítással, mivel fókuszál a hallgatók fejlődésére, elérendő tanulási eredményeire - még ha azok esetleg nem is mindig expliciten megfogalmazottak. Továbbá a tanuló- és tanulásközpontú szemlélet a tanulási eredmények alapú tanításban az erős, konstruktív összehangolást is támogatja, hiszen a tanulási folyamat támogatása egyúttal a tervezés, a tanulási-tanítási tevékenység és az értékelés összehangolását is jelenti (Biggs - Tang, 2003; Lukács - Derényi, 2017). Végül a tanulásközpontú megközelítések a tanulás folyamatát és annak támogatását kiterjesztik a tanárok, közösségek tanulására is.

Összességében az oktatói kompetenciák azonosítása nem egyszerű, problémamentes feladat, ugyanakkor explicitté tételük a felsőoktatás számára és az oktatóknak maguknak is sokkal differenciáltabb képet adhat az oktatói tevékenységekről, annak minőségi szempontjairól, mint mondjuk a hazai gyakorlatban jellemző, az oktatási tevékenységet a megtartott órák számához kötő gyakorlat (például Harden - Crosby, 2000). Legfőbb előnyként értelmezhető, hogy az oktatói kompetenciák azonosításában fő szerepet játszanak az eredményes tanítással kapcsolatos kutatási eredmények. A tanítás minőségét a hallgatói tanulás eredményességéhez kötik, s így a kompetenciakeretek erősesen építenek a tanulásközpontú megközelítésekre. A kompetencia fogalmának elfogadott értelmezése, hogy olyan, a szakmai kontextusban alkalmazható komplex, pszichikus sajátosságok, amelyek az ismeretek, képességek, attitűdök komponenseit egyaránt tartalmazzák (Falus, 2006; Daniels, 2016). Meghatározásukban két fő folyamat játszik lényegi szerepet: egyrészt az oktatói szerepek, tevékenységek összegyűjtése, elemzése, hiszen ezek alapján lehet azonosítani azokat a pszichikus feltételeket, amelyek szükséges a tevékenységek elvégzéséhez; másrészt a kompetenciák rendszeres újraértelmezése, egyeztetése, mivel azok az intézményi kontextusok és az érintettek eredményes tanításról alkotott értelmezései szerint, valamint az idő múlásával is folyamatosan változhatnak (Falus, 2006; Lukács - Derényi, 2017).

\section{Az oktatói kompetenciák lehetséges keretrendszerei}

Az oktatói kompetenciák és sztenderdek keretrendszerének meghatározására számos kísérlet született, ezek kialakítása történhet országos szintủ követelményként, kötődhetnek egyes felsőoktatási intézményekhez, intézményi prioritásokhoz, sőt vonatkozhatnak egyes szak-, tudományterületek oktatói kompetenciáira 
is - jellemzően a pedagógusképzőkre és az orvosi képzés oktatóira (például Melief és mtsai, 2012-2013). A kilencvenes évektől kezdve több országban - például Ausztráliában, az Egyesült Királyságban, Kanadában, az Amerikai Egyesült Államokban, Hollandiában - jelentek meg az oktatói kompetenciák meghatározására tett kezdeményezések, aminek kidolgozásában elsősorban szakmai szervezetek és a felsőoktatási intézmények vettek részt, az oktatói közösségek pedig inkább véleményezőként, a kipróbálás aktív résztvevőiként jelentek meg (Chalmers és mtsai, 2014; Ödalen és mtsai, 2019). Mivel a hazai kontextusban az oktatói kompetenciákról eddig még nem indult el szakmai vita - ez alól az egyedüli kivétel a pedagó gusképzők kompetenciáinak kidolgozására vonatkozó kezdeményezés (Falus, 2015) - az oktatói kompetenciák értelmezéséhez már kialakított, külföldi rendszerekből fogunk kiindulni (vö. Falus, 2006), elsősorban Ausztrália és az Egyesült Királyság gyakorlatából. Majd ezeket a keretrendszereket alakítjuk át, egészítjük ki a hazai felsőoktatási tevékenységek, tapasztalatok figyelembevételével. Az alábbiakban a lehetséges kompetenciaterületek értelmezésének, kialakításának módját mutatjuk be.

A keretrendszerek tartalmukban Tiegelaar és mtsai (2004) elemzése szerint a következő főbb területekre fókuszálnak: 1 . a tervezés, a tanítás, a tanulás támogatása és az értékelés területeire 2. a tudomány-, a szakterület tanítására 3. a szervezési és az együttműködési kompetenciákra, 4. a tudományos vagy a szélesebb oktatói szerephez kötődő kompetenciákra. Általában ez utóbbi kategóriába tartozik a folyamatos szakmai fejlődés, a reflektálás, a felsőoktatás értékei melletti elköteleződés. Kiindulópontként használtuk ezt a csoportosítást, amelyet a kutatók ( Tiegelaar és mtsai, 2004) az oktatói értékelések révén is igyekeztek megerősíteni. Vizsgálatukban az oktatók a szervezési kompetenciaelemek (például időmenedzsment, PhD-hallgatók tanítási tevékenységének szervezése, támogatása) fontosságával nem értettek egyet, ezeket nem tartották igazán szakmai-tanítási szempontból lényeges és egységesen elfogadható kritériumoknak, ezért ezt el is hagytuk, és az adott kompetenciaterületnek csak a szakmai együttmüködés komponensét tartottuk meg.

Mindezeket figyelembe véve a kompetencia-keretrendszer kidolgozásakor fó alapelvünk volt, hogy minél konkrétabb, tevékenységekhez kötődő kategóriákat használjunk, valamint hogy az angolszász területeken már széles körben értett és használt, tanulásközpontú pedagógiai alapfogalmakat (például tanulási környezet, tanulási tevékenység) közérthetőbb terminusokkal helyettesítsük (1. táblázat). 
Pedagógusképzés • 18(46), 2019/1-2.

\begin{tabular}{|c|c|c|}
\hline $\begin{array}{c}\text { Ausztrál Egyetemi Oktatás } \\
\text { Kritériumainak és Szten- } \\
\text { derdjeinek keretrendszere } \\
\text { (AUTCAS) }\end{array}$ & $\begin{array}{c}\text { Az Egyesült Királyság } \\
\text { Szakmai Sztenderdjeinek } \\
\text { keretrendszere (UKPSF) }\end{array}$ & $\begin{array}{c}\text { A hazai felsőoktatásban dol- } \\
\text { gozó oktatók lehetséges kom- } \\
\text { petenciaterületei }\end{array}$ \\
\hline $\begin{array}{l}\text { A tanulási tevekénységek } \\
\text { fejlesztése, tervezése }\end{array}$ & $\begin{array}{l}\text { Tanulási tevékenységek } \\
\text { és/vagy képzések tervezé- } \\
\text { se }\end{array}$ & $\begin{array}{l}\text { Kurzusok tervezése, fejlesz- } \\
\text { tése } \\
\text { Képzések fejlesztése, moni- } \\
\text { torozása }\end{array}$ \\
\hline $\begin{array}{l}\text { Tanítás, a hallgatók tanu- } \\
\text { lásának támogatása }\end{array}$ & $\begin{array}{l}\text { Tanítás és/vagy tanulástá- } \\
\text { mogatás }\end{array}$ & $\begin{array}{l}\text { A hallgatók tanulásának tá- } \\
\text { mogatása, facilitálása }\end{array}$ \\
\hline $\begin{array}{l}\text { Értékelés és a hallgatók } \\
\text { tanulására vonatkozó visz- } \\
\text { szajelzés adása }\end{array}$ & $\begin{array}{l}\text { Értékelés és visszajelzés } \\
\text { adása a hallgatóknak }\end{array}$ & $\begin{array}{l}\text { A hallgatók tanulásának, } \\
\text { eredményeinek értékelése, } \\
\text { visszajelzések nyújtása } \\
\text { A tudománv- és szakterület }\end{array}$ \\
\hline--- & --- & $\begin{array}{l}\text { meghatározó és új elemei- } \\
\text { nek szakszerű tanítása } \\
\text { Online tanulási környezetek } \\
\text { tervezése, fejlesztése }\end{array}$ \\
\hline $\begin{array}{l}\text { Hatékony tanulási kör- } \\
\text { nyezetek fejlesztése, tanu- }\end{array}$ & Hatékony tanulási környe- & $\begin{array}{l}\text { A képzésbe újonnan érkező } \\
\text { hallgatók tanulásának segí- } \\
\text { tése }\end{array}$ \\
\hline $\begin{array}{l}\text { lók támogatása és tanács- } \\
\text { adás }\end{array}$ & $\begin{array}{l}\text { zetek, tanulástámogatás és } \\
\text { tanácsadás fejlesztése }\end{array}$ & $\begin{array}{l}\text { A képzésbe újonnan érkező } \\
\text { hallgatók egyetemi szociali- } \\
\text { zációjának segítése, mento- } \\
\text { rálása }\end{array}$ \\
\hline & & Tehetséggondozás \\
\hline $\begin{array}{l}\text { A tudományos megközelí- } \\
\text { tés, kutatás és szakmai te- } \\
\text { vékenység integrálása a } \\
\text { tanítással és a hallgatók }\end{array}$ & & $\begin{array}{l}\text { A saját tanítási gyakorlat } \\
\text { elemzése, vizsgálata, értéke- } \\
\text { lése }\end{array}$ \\
\hline $\begin{array}{l}\text { tanulasanak tamogatasa- } \\
\text { val }\end{array}$ & $\begin{array}{l}\text { Folyamatos szakmai tejló- } \\
\text { dés a szakterületen és pe- }\end{array}$ & \\
\hline A gyakorlat értékelése és & $\begin{array}{l}\text { dagógiájában, integrálva a } \\
\text { kutatást, az oktatásra vo- }\end{array}$ & $\begin{array}{l}\text { Kollégákkal való együttmü- } \\
\text { ködés az oktatás során }\end{array}$ \\
\hline $\begin{array}{l}\text { a folyamatos szakmai fej- } \\
\text { lődés }\end{array}$ & $\begin{array}{l}\text { natkozó tudományosságot } \\
\text { és a szakmai tevékenység } \\
\text { értékelését }\end{array}$ & $\begin{array}{l}\text { Egyetemen kívüli partne- } \\
\text { rekkel való együttműködés } \\
\text { az oktatás érdekében }\end{array}$ \\
\hline $\begin{array}{l}\text { Szakmai és személyes ha- } \\
\text { tékonyság }\end{array}$ & & $\begin{array}{l}\text { Új oktatási módszerek ki- } \\
\text { próbálása, megosztása az } \\
\text { egyetemen (például projekt, } \\
\text { tükrözött osztályterem) }\end{array}$ \\
\hline
\end{tabular}

1. táblázat: Az oktatók szakmai kompetenciái Ausztráliában (Chalmers és mtsai, 2014) és az Egyesült Királyságban (UKPSF, 2011), valamint az oktatói kompetenciák lehetséges hazai területei

A kialakított rendszer főbb elemei a következőképpen alakultak: a tervezés, tanulástámogatás és értékelés fő területeit külön tartottuk, ahogyan a két példaként használt keretrendszerre is jellemző, hiszen ezek a tanítás alaptevékenységei. Bár 
az angolszász keretrendszerekben a tudomány-, szakterület tanítása az előbbi három kompetenciaterületbe beleértődik, fóként amiatt, hogy a hazai kontextusban kevésbé elterjedt a tanulásközpontú megközelítés, ráadásul a jó oktatók ismérvei esetében egy 2014-es kutatásban ez a terület az elsők közt és külön szerepelt (Soreco Research, 2014 idézi Berács és mtsai, 2015), szükségesnek tartottuk külön elemként beépíteni a rendszerbe. A nemzetközi példákban a tanulási tevékenységek tervezése magába öleli a kurzusok és a képzések szintjén történő tervező munkát is, s bár fontosnak tartjuk a két szint szerves összekapcsolását, a hazai kontextusban kettéválasztottuk a kompetenciaterületet a jobban érthetőség kedvéért. A hatékony tanulási környezet, tanulástámogatás és tanácsadás kompetenciaterületét összesen négy területre bontottuk. A részletezés kapcsán az általános elveinken túl fontos volt, hogy a tanulásközpontú megközelítés is érvényesüljön, a kurzusokon túli lehetséges tanulástámogatás is hangsúlyossá váljon, valamint a jól értelmezhető új feladatok, felsőoktatási kihívások is megjelenjenek (például a belépő hallgatók támogatása). A keretrendszerekben Tiegelaarék (2004) utolsó két csoportjának kompetenciaterületei mutatják a legnagyobb variabilitást, azaz az együttműködési és a tudományos és tágabb oktatási szerephez kötődő kompetenciaterületek. Itt alapvetően inkább a részletesebb ausztrál keretrendszert használtuk kiindulópontként, hangsúlyoztuk az oktatói együttmüködést, valamint az egyetemen kívüli partnerekkel való együttműködést is, ami részben a kutatás, a szakmai tevékenységek és a tanítás integrálásához kapcsolódik. A szakmai fejlődés alaptevékenységéhez kötődően összevontuk a gyakorlat értékelésének és vizsgálatának, kutatásának (scholarship of teaching) területét, mivel az utóbbi gyakorlata kevéssé ismert hazánkban, valamint külön kiemeltünk egy az innovációhoz kötődő kompetenciaterületet, az új oktatási módszerek kipróbálását. Összességében így az 5-7 elemes szakmai sztenderdek helyett egy 13 területre kiterjedő kompetencialistát alkottunk. Ez a lista vállaltan nem ugyanolyan részletezettséggel vont be egyes kompetenciaterületeket: az újabb felsőoktatási feladatokhoz kötődő elemek részletesebben jelennek meg. A cél ugyanakkor itt nem egy keretrendszer kialakítása volt, hanem az oktatói értelmezések, preferenciák, értékelések minél pontosabb feltárása. 


\section{A képzési területek jellemzői és a tanítási tapasztalatok szerepe}

Az oktatói kompetenciák keretrendszerei kutatásokra is támaszkodva azt igyekeznek leírni, hogy az eredményes tanításhoz milyen oktatói kompetencia-feltételek szükségesek, függetlenül attól, hogy az oktatók milyen képzési területen tanítanak, kezdő vagy éppen tapasztalt oktatók. Sokszor éri kritika ezeket a keretrendszereket, hogy túl általánosak annak érdekében, hogy különböző tudomány- és szakterület tanítási sajátosságaira is érvényesek legyenek. A kompetencia-rendszerek alapján létrehoznak sztenderdeket, kompetenciaszinteket (például UKPSF, 2011; Thomas és mtsai, 2016), hogy ezzel segítsék a kezdő oktatók és a karrierjük különböző fázisaiban lévő oktatók számára is a kihívást jelentő fejlődési célok kitűzését és bizonyítását. A hazai felsőoktatásban nincsenek ilyen kiépített keretrendszerek, ezért is válhat fontossá első lépésként az oktatói elképzelések differenciált feltérképezése.

A tanítással kapcsolatos nézetek és megközelítések esetében a nemzetközi kutatások elméleti alapon (Shulman, 2005) és empirikus vizsgálatokban (például Lueddeke, 2003; Lindblom-Ylänne és mtsai, 2006; Stes - Van Petegem, 2014; Kálmán és mtsai, 2019) is találtak különbségeket tudomány-, illetve szakterületek szerint. Az empirikus vizsgálatok szerint a „puha” tudományok oktatói körében erősebb a tanulásközpontú megközelítés, mint a „kemény” tudományok képviselőinél. Továbbá az is látszik, hogy nagyobbak a különbségek a „puha” és „kemény” tudományterületek közt, mint az alap- és alkalmazott tudományterületek közt (vö. Lindblom-Ylänne és mtsai, 2006). A 2014-ben hazai oktatók körében végzett oktatással kapcsolatos vizsgálat is feltárt tudományterületi különbségeket, például az új tanulásszervezési megoldásokat, módszereket inkább a művészeti területen oktatók tartják fontosabbnak, míg a hittudományi, műszaki, illetve természettudományos területen dolgozók kevésbé (Soreco Research, 2014 idézi Berács és mtsai, 2015). Bár ezek a vizsgálatok a tanítási megközelítések, tevékenységek kapcsán tártak fel különbségeket, feltételezhető, hogy azok az új felsőoktatási feladatok, amelyek inkább a tanulásközpontú megközelítésekhez kapcsolódnak (például a képzésbe újonnan érkező hallgatók tanulásának, szocializációjának támogatása, mentorálás) szintén mutatnak majd képzési területenként eltéréseket.

A szakmai fejlődés a karrier során egyfajta előrelépést feltételez az egyes oktatói kompetenciákban is. Ugyanakkor egyre erősödik a személyes, egyedi tanulási út elfogadása, az egyéni motívumok és a kontextuális faktorok együttes rendszer- 
szintű értelmezésének hangsúlyozása (Rapos, 2016; Thomas és mtsai, 2016), amelyek differenciáltabbá teszik az oktatói kompetenciák változásáról alkotott képet. $\mathrm{Az}$ empirikus kutatások - egyelőre még főként a közoktatás (Richter és mtsai, 2011; de Vries és mtsai, 2014, Rapos, 2016), de részben a felsőoktatás területén is (Ferman, 2001; Kálmán, 2016, 2019; Kálmán és mtsai, 2019) - azt mutatják, hogy a tanulásközpontú megközelítést vallók nyitottabbak a szakmai fejlődésre (de Vries és mtsai, 2013); valamint hogy a szakmai fejlődés és tanulás módja és intenzitása változik a karrier során (Richter és mtsai, 2011; Kálmán, 2016; Rapos, 2016; Kálmán és mtsai, 2019). A felsőoktatásban a kezdő oktatók inkább az informális, kollegiális tudásmegosztás útjait választották, míg a tapasztaltabbak nyitottabbak voltak a kísérletezésre (Ferman, 2001; Kálmán, 2019; Kálmán és mtsai, 2019). A pedagógiai kompetenciáikat általánosságban kevésbé jónak ítélő oktatók egy hazai vizsgálatban inkább a csoportos mentorálásra, informális beszélgetésekre voltak nyitottak, míg a pedagógiai kompetenciáikat inkább jónak ítélők azok, akik szívesen olvasnak pedagógiai szakirodalmat, járnak konferenciákra. Az eredmények alapján az látszott, hogy azok az oktatók, akik kevésbé jónak észlelik kompetenciáikat, inkább az informális utakra nyitottabbak (Kálmán, 2016). Összességében tehát még nincs elég információnk arról, hogy az oktatói kompetenciák fontosságának és eredményességének észlelése és a szakmai fejlődés és tanulás útjai hogyan kapcsolódnak össze. Az látszik, hogy az észlelt kompetenciák lényegesek lehetnek a szakmai fejlődés útjainak tervezésében, valamint hogy mind az észlelt kompetenciák, mind a szakmai fejlődés és tanulás útjai differenciáltan alakulnak az oktatói karrier során. Jelen kutatás ezért az oktatói kompetenciák és a tanítási tapasztalatok összefüggését is részletesebben vizsgálja.

\section{Kutatási kérdések}

A hazai felsőoktatás oktatóinak körében végzett feltáró jellegű kutatás hosszú távú célja, hogy a felsőoktatásban is megerősödő oktatásfejlesztés, az oktatók szakmai fejlődésének megalapozott tervezéséhez hozzájáruljon. Ebben a tanulmányban ezért az oktatói kompetenciákról alkotott oktatói elképzelések feltárása áll a középpontban. A szakirodalmi elemzésekre, az elemzett oktatói keretrendszerekre építve a következő kutatási kérdésekre keressük a válaszokat:

- Az oktatók hogyan értelmezik kompetenciáikat, azaz milyen oktatói kompetenciákat tartanak fontosnak és mennyire érzik eredményesnek magukat e kompetenciaterületeken? 
- Az oktatói elképzelésekben azonosíthatóak-e különbségek a képzési területek, valamint a tanítási tapasztalatok szerint?

\section{A kutatás módszere és mintája}

A hazai oktatók körében végzett reprezentatív kutatás egy online kérdőíves vizsgálatra épül annak érdekében, hogy a hazai oktatók értelmezéseit minél átfogóbban tudja feltárni, mivel a korábbi vizsgálatok inkább egy-egy intézményhez, oktatói csoporthoz kötődtek (például Kálmán, 2016; Kovács - Kereszty, 2016). A kérdőív a következő fö területekre tért ki: a tanításra, az oktatói kompetenciákra, a saját szakmai fejlődésre és tanulásra, valamint az ehhez szükséges támogatás sajátosságaira, valamint az oktatói háttéradatokra. Mindezekből jelen tanulmányban az oktatói kompetenciákkal kapcsolatos elképzeléseket mutatjuk be. Az oktatói kompetenciák feltárása a korábban bemutatott keretrendszerek elemzése alapján a hazai kontextusra adaptált rendszer mentén történt, feldolgozásához leíró statisztikai eljárásokat alkalmaztam. A képzési területek és a tanítási tapasztalatok szerinti különbségek elemzésénél az oktatói kompetenciák esetében a Kolmogorov-Smirnov-próba szignifikáns volt, ezért a Kruskal-Wallis-próbát alkalmaztam.

Az online kérdőívet a 2018 májusában és júliusában töltötték ki az oktatók. Az 1744 kitöltőből 1505-en dolgoztak oktatói státuszban. Ebből az adattisztítás és a reprezentativitás biztosítása után végül 1128 oktató eredményeit sikerült feldolgozni. Az oktatói minta országos szinten régió (Kelet-Magyarország, KözépMagyarország és Nyugat-Magyarország), fenntartó és képzési terület szerint reprezentatív. A képzési területek szerinti reprezentatív mintát a karok fó profilja szerint terveztük meg. Az egyes képzési területeken hozzávetőlegesen az oktatók 10\%-a került be a mintába. A társadalom-, természet- és bölcsészettudományi terület felülreprezentált volt, ezért véletlenszerűen csökkentettük a részmintákat a reprezentativitás megtartása érdekében (2. táblázat), figyelve arra, hogy a középmagyarországi állami fenntartású intézmények se kerüljenek túlsúlyba. A művészet- és művészet-közvetítési képzési területet az alacsony elemszám miatt összevontuk. 
Kálmán Orsolya

\begin{tabular}{l|llll}
\hline \multicolumn{1}{c|}{ Képzési terület } & $\begin{array}{c}\text { Csak egy } \\
\text { képzési } \\
\text { területen }\end{array}$ & $\begin{array}{c}\text { Több képzési } \\
\text { területen }\end{array}$ & $N$ & $\begin{array}{c}\text { Az országos } \\
\text { populáció 10\%-a }\end{array}$ \\
\hline Agrár & 49 & 34 & 83 & 78 \\
Államtudomány & 7 & 21 & 28 & 34 \\
Bölcsészettudomány & 137 & 86 & 223 & 182 \\
Gazdaságtudomány & 82 & 60 & 142 & 166 \\
Hittudomány & 11 & 14 & 25 & 22 \\
Informatika & 52 & 60 & 112 & 74 \\
Jogi & 40 & 28 & 68 & 40 \\
Müszaki & 117 & 83 & 200 & 174 \\
Müvészet és művészet- & 17 & 16 & 33 & 52 \\
közvetítési & & & & \\
Orvos- és & 176 & 35 & 211 & 244 \\
egészségtudomány & & & & \\
Pedagógusképzés & 34 & 85 & 119 & 122 \\
Sporttudomány & 17 & 23 & 40 & 22 \\
Társadalomtudomány & 17 & 81 & 98 & 66 \\
Természettudomány & 62 & 64 & 126 & 102
\end{tabular}

2. táblázat: Az oktatói minta képzési területek szerinti megoszlása $(\mathrm{N}=1128)$

A képzési területek elemzéséhez a következő alcsoportokat alakítottam ki: 1. azon oktatók, akik csak az adott képzési területen tanítanak, 2. azon oktatók, akik az adott képzési terület mellett máshol is tanítanak, és végül 3. akik nem tanítanak az adott képzési területen. A nemzetközi kutatások (Biglan, 1973; Becher, 1994) gyakran a kemény-puha, tiszta-alkalmazott tudományterületek csoportjait használják a különbségek vizsgálatához. Viszont a tudományterületek és képzések átalakulása, interdiszciplináris jellege, szakmai orientációja mind hozzájárulnak e kategóriák nehezebb használatához (vö. Trowler, 2014), ezért a statisztikai elemzésekben az eredeti képzési területeket tartottuk meg annak érdekében, hogy árnyaltabb képet kapjunk a hazai felsőoktatásról, bár az adatok értelmezésében felhasználjuk a fentebbi tipológiákat is.

A tanítási tapasztalatok esetében négy kategóriába rendeztük az adatokat: 1. a 9 évnél kevesebb ( $\mathrm{n}=226)$, 2. a 10-19 év közti $(\mathrm{n}=365)$, 3. a 20-29 év közti $(\mathrm{n}=255)$, valamint 4. a több mint 30 év tanítási tapasztalattal $(n=281)$ rendelkező oktatókra. A 9 évnél kevesebb ideje tanítók kategóriája először két kategóriaként jelent meg, mivel a kezdő oktatói időszakot általában az első 3-5 évre vonatkoztatjuk. Ugyanakkor ebbe a kategóriába csak az oktatók kis száma tartozott, ezért döntöttünk az összevonás mellett. 


\section{Eredmények}

Az eredményeket a kutatási kérdések mentén mutatjuk be. Először az oktatók vélekedését az oktatói kompetenciák fontosságáról, és arról, hogy mennyire érzik eredményesnek magukat ezeken a területeken, valamint azt, hogy e kettő hogyan kapcsolódik össze az elképzeléseikben. Majd az észlelt kompetenciák esetében mivel ez nagyobb eltéréseket mutatott, és a hosszú távú fejlesztési célok szempontjából is különösen meghatározó - összegezzük a képzési területek és a tanítási tapasztalatok szerint megmutatkozó különbségeket.

\section{Az oktatói kompetenciák fontossága és az észlelt kompetenciák}

Az oktatók a 13 kompetenciaterület közül 8 esetben a 10-es skálán 8-nál magasabbra értékelték a kompetenciák fontosságát, ami magas szintű elfogadottságot jelent (3. táblázat). Azt lehet mondani, hogy a tervezés, tanulásszervezés, értékelés folyamatait és az új szakmai tartalmak tanítását kiemelten lényegesnek tartják. A szakmai fejlődéshez kötődő kompetenciaterületek ezzel szemben már vegyes képet mutatnak; a tanulási környezetek és a hallgatói csoportok támogatásához kötődőek pedig inkább a kevésbé lényeges területek közé tartoznak. 


\begin{tabular}{|c|c|c|c|c|}
\hline & \multicolumn{2}{|c|}{ Fontosság } & \multicolumn{2}{|c|}{ Észlelt eredményesség } \\
\hline & Rangsor & $\begin{array}{c}\text { Átlag és } \\
\text { szórás }\end{array}$ & Rangsor & $\begin{array}{l}\text { Átlag és } \\
\text { szórás }\end{array}$ \\
\hline $\begin{array}{l}\text { Tehetséges hallgatók tanulásának, fejlődé- } \\
\text { sének segítése }\end{array}$ & 1. & $9,13(1,25)$ & 5. & $8,20(1,86)$ \\
\hline $\begin{array}{l}\text { A tudomány-, szakterület meghatározó és } \\
\text { új elemeinek szakszerú tanítása }\end{array}$ & 2. & $8,99(1,33)$ & 1. & $8,51(1,56)$ \\
\hline $\begin{array}{l}\text { A hallgatók tanulásának, eredményeinek } \\
\text { értékelése, visszajelzés nyújtása }\end{array}$ & 3. & $8,82(1,47)$ & 3. & $8,39(1,71)$ \\
\hline Kurzusok tervezése, fejlesztése & 4. & $8,66(1,62)$ & 2. & $8,49(1,87)$ \\
\hline $\begin{array}{l}\text { A hallgatók tanulásának támogatása, facili- } \\
\text { tálása }\end{array}$ & 5. & $8,50(1,64)$ & 6. & $7,84(1,94)$ \\
\hline $\begin{array}{l}\text { Kollégákkal való együttmúködés az oktatás } \\
\text { során }\end{array}$ & 6. & $8,41(1,85)$ & 4. & $8,28(1,99)$ \\
\hline $\begin{array}{l}\text { A saját tanítási gyakorlat elemzése, vizsgá- } \\
\text { lata, értékelése }\end{array}$ & 7. & $8,27(1,97)$ & 7. & $7,69(2,20)$ \\
\hline Képzés/szak fejlesztése, monitorozása & 8. & $8,16(2,11)$ & 8. & $7,00(2,70)$ \\
\hline $\begin{array}{l}\text { A képzésbe újonnan érkező hallgatók ta- } \\
\text { nulásának segítése }\end{array}$ & 9. & $7,95(2,00)$ & 10. & $6,84(2,45)$ \\
\hline $\begin{array}{l}\text { Egyetemen kívüli partnerekkel való } \\
\text { együttműködés az oktatás érdekében }\end{array}$ & 10. & $7,58(2,26)$ & 9. & $6,87(2,80)$ \\
\hline $\begin{array}{l}\text { Új oktatási módszerek kipróbálása, meg- } \\
\text { osztása az egyetemen (például projekt, } \\
\text { tükrözött osztályterem...) }\end{array}$ & 11. & $7,17(2,44)$ & 11. & $6,53(2,79)$ \\
\hline $\begin{array}{l}\text { A képzésbe újonnan érkező hallgatók } \\
\text { egyetemi szocializációjának segítése, men- } \\
\text { torálása }\end{array}$ & 12. & $6,37(2,59)$ & 12. & $5,64(2,78)$ \\
\hline $\begin{array}{l}\text { Online tanulási környezetek tervezése, ki- } \\
\text { vitelezése }\end{array}$ & 13. & $6,10(2,66)$ & 13. & $5,27(2,87)$ \\
\hline
\end{tabular}

3. táblázat: Az oktatói kompetenciák fontossága és észlelt eredményessége egy 1-10 terjedő skálán $(\mathrm{N}=960)$

Ha részleteiben nézzük, akkor az oktatók a legfontosabb kompetenciaterületnek a tehetséges hallgatók tanulásának segítését tartják, ami fontosságát tekintve teljesen elszakad a többi hallgatói csoport (például újonnan érkezők) speciális támogatásától. Ezt követik azok a kompetenciák, amelyek elsősorban a szakmai tartalmak tanításához, értékeléséhez, tervezéséhez kötődnek, azaz a szakterület új elemeinek tanítása; a hallgatók tanulásának, eredményességének értékelése; valamint a kurzustervezés. Ezek a kompetenciaterületek tehát elsősorban nem a tanulásközpontú pedagógiák megvalósításához szükségesek, fóként, ha azt is számításba vesszük, hogy a korábbi kutatások szerint (Vámos, 2011; Soreco Research, 2014 idézi Berács és mtsai, 2015) az értékelés területén nem jellemző az új tanulásközpontú, tanulási eredményekhez kötődő megoldások keresése. Ugyanakkor a 
legfontosabbak közt szerepelnek a hallgatók tanulásának támogatása, facilitálása is, ami a tanulásközpontú irány elfogadottságának növekedését is jelzi.

A szakmai fejlődéshez és tanuláshoz kötődő kompetenciaterületek közül a kollégákkal való együttműködés és a saját tanítási gyakorlat elemzése, vizsgálata, értékelése az, ami kiemelten lényeges az oktatók számára. Ezzel összevetve viszont az egyetemen kívüli partnerekkel való együttmúködés vagy az új oktatási módszerek kipróbálása, megosztása kevésbé fontos szempont. Mindez a szakmai fejlődés és tanulás területén azt mutatja, hogy inkább a saját egyéni tanítási gyakorlatra figyelnek, és hogy a szélesebb körű együttmüködésre, tudásmegosztásra kevésbé nyitottak.

A legkevésbé lényeges területek azok, amelyek a tanulási környezetekhez, hallgatói csoportok támogatásához kötődnek. Ez alól csak a tehetséges hallgatók segítése kivétel. A hazai oktatók ezek közül is legkevésbé az online tanulási környezetek tervezését, valamint az újonnan érkező hallgatók szocializációjának segítését tartják fontos területnek. Ezek azok a területek egyébként, amelyek leginkább újfajta feladatokat jelentenek a felsőoktatás számára.

Összevetve az oktatói kompetenciák megítélt fontosságát és észlelt eredményességét azt találtuk, hogy az oktatók éppen azokon a területeken érzik magukat a legkevésbé kompetensnek, amely területeket egyébként nem is tartanak annyira fontosnak. Az online tanulási környezetek fejlesztése, a képzésbe újonnan érkező hallgatók szocializációjának támogatása, az új oktatási módszerek kipróbálása és az egyetemen kívüli partnerekkel való együttmúködés bár mind fontosságban, mind az észlelt eredményesség szempontjából sereghajtó, ezeknél a válaszoknál a legnagyobb szórás. Mindez azt is jelenti, hogy az oktatók éppen ezekről a területekről gondolkodnak igen különbözően, mondhatni szélsőségesen.

A fontosabbnak ítélt kompetenciaterületek esetében viszont ez a megfeleltetés már nem ilyen egyértelmű. Legeredményesebbnek a szakterületük újdonságainak tanításában, a kurzusok tervezésében, fejlesztésében és a hallgatók tanulásának, eredményeinek értékelésében tartják magukat. A tehetséggondozásban és a hallgatók tanulásának facilitálásában az előbbieknél és a fontossághoz viszonyítva is kevésbé érzik magukat kompetensnek. Bár a hallgatói támogatás kompetenciái alá csoportosítottuk a tehetséges tanulók segítését, a képzésbe újonnan érkezők tanulásának és szocializációjának támogatását is, jól látszik, hogy a felsőoktatás oktatói ezek közül messze a tehetséggondozást tartják a leglényegesebbnek, s magukat is eredményesebbnek e területen. Összességében tehát a sokféle hallgatói csoport 
támogatása nem egységesen lényeges az oktatók számára, és nem is érzik magukat egyformán eredményesnek. Azaz a tanulástámogatáshoz általában kapcsolódó elképzelés, hogy az minden hallgató támogatásához kötődik - ilyen formában nem jelenik meg a hazai felsőoktatásban.

Érdemes összevetni azt is, hogy az oktatók vélekedésében milyen módon kapcsolódik össze az adott kompetencia fontossága és saját eredményességük megítélése, hiszen amennyiben az oktató fontosabbnak tart egy adott kompetenciaterületet, mint amennyire magára nézve jellemzőnek, az ösztönzően hathat a szakmai fejlődésére és tanulására. Mindehhez három oktatói csoportot alakítottunk ki: 1. akik fontosabbnak tartják, mint amennyire eredményesnek észlelik az adott kompetenciaterületet, 2. akik eredményesebbnek látják magukat, mint amennyire fontosnak érzékelik a kompetenciaterületet, és végül 3. akik ugyanúgy ítélik meg az adott kompetencia fontosságát és eredményességét. Az alábbi ábrán (1. ábra) csak az első két csoport eredményeit mutatjuk meg.

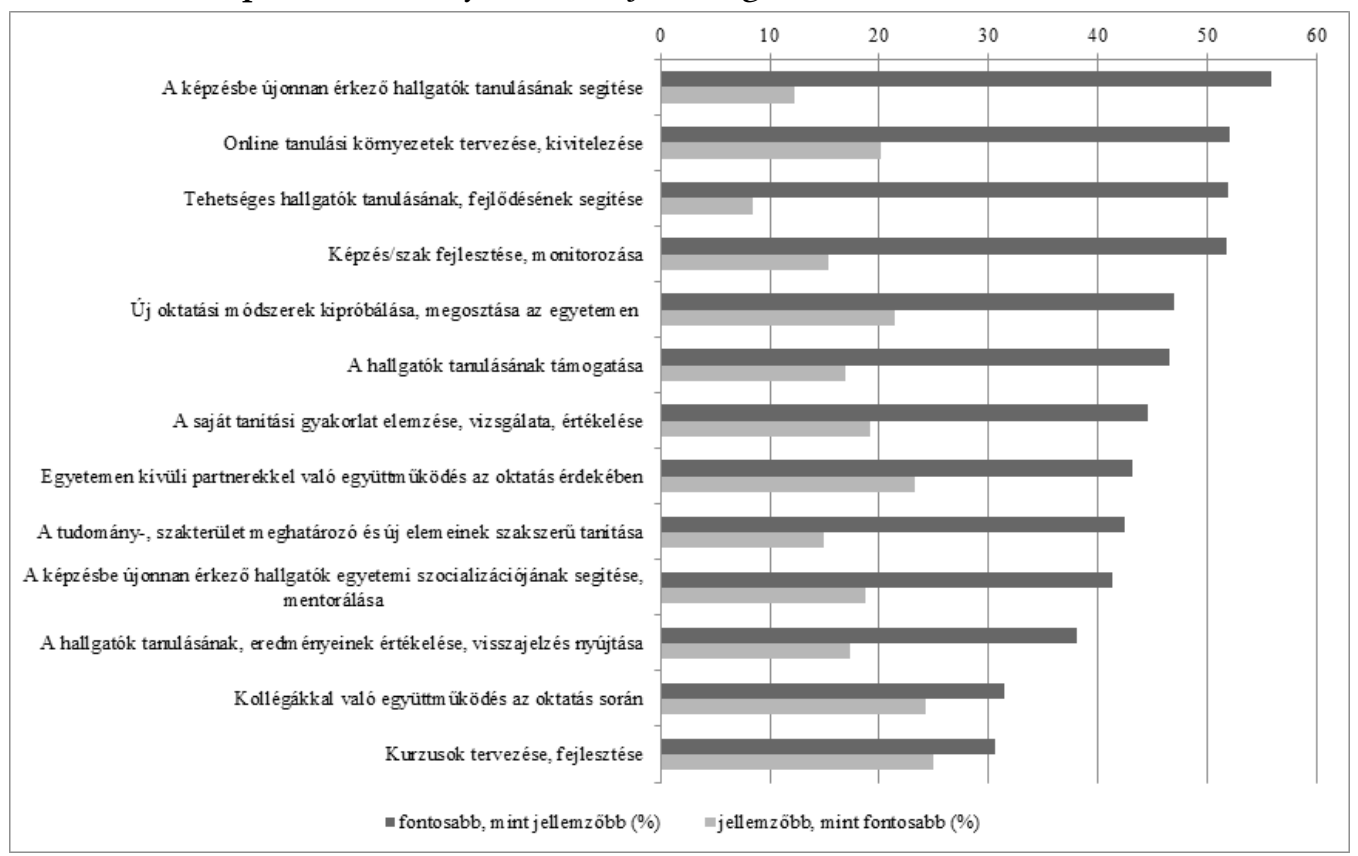

1. ábra: Az oktatói kompetenciaterületek fontosságának és eredményességének megítélése $(\mathrm{N}=960)$

Az oktatók nagyobb része fontosabbnak, mint amennyire magára nézve jellemzőnek látja a kompetenciákat, ami ugyan nem meglepő, de az oktatók szakmai fejlődése szempontjából lényeges kiindulópont lehet. Az oktatók több mint 50\%-a érezte úgy, hogy ahhoz képest, milyen nagy mértékben lényeges az újonnan érke- 
ző hallgatók tanulásának támogatása, továbbá az online tanulási környezetek tervezése, fejlesztése, illetve a tehetséggondozás vagy a képzés fejlesztése, annyira nem észlelik erősnek kompetenciáikat ezeken a területeken. A négy elemből három erőteljesen a felsőoktatás új feladataihoz tartozik: felértékelődött az új hallgatók támogatásának szükségessége, csakúgy, mint az online tanulás tervezése és a szakok professzionális gondozása. A tehetséggondozás ezzel összevetve egy hagyományosabb, de az oktatók számára messze a legfontosabb feladat- és kompetenciakör. Ráadásul ez az a terület, ahol a legkisebb azon oktatói csoport aránya, aki jobbnak érzékeli a kompetenciáját, mint amennyire jellemzőnek.

A kurzusok tervezése, fejlesztése és a kollégákkal való együttmúködés területei azok, amelyekben az oktatók a legkevésbé nyitottak a változtatásokra. Ezeknél a területeknél gondolja a legkevesebb oktató, hogy fontosabbak lennének, mint amennyire jellemző rájuk. Ráadásul ezeknél a kompetenciáknál az oktatók hozzávetőlegesen 25\%-a érzi úgy, hogy eredményesebb az adott területen, mint amenynyire fontosnak tartja azt. Ezeken kívül az egyetemen kívüli partnerekkel való együttműködés; valamint az új oktatási módszerek kipróbálásának, megosztásának területeinél látjuk még, hogy közel az oktatók egynegyede hisz abban, hogy kevésbé fontosak e területek, mint amennyire jellemző rájuk. Pedig ezek a kompetenciaterületek jelentős szerepet játszhatnak a felsőoktatás képzési, tantervi fejlesztéseiben, valamint az oktatói szakmai fejlődés és tanulás eredményes módjainak megvalósításában (lásd együttműködésre épülő tanulás, fejlesztésbe, innovációba ágyazott tanulás).

\section{Az oktatói kompetenciák észlelt eredményessége a különbözö képzési területeken}

$\mathrm{Az}$ egyes kompetenciaterületek eredményességének észlelése eltérő mértékben különbözik a képzési területek szerint. Az észlelt kompetenciák a következő három esetben függnek legkevésbé a képzési területektől: a tudomány- és szakterület meghatározó, illetve új elemeinek szakszerủ tanítása; a kurzusok tervezése, fejlesztése, valamint a kollégákkal való együttműködés kapcsán. A fentebbi kompetenciák mindegyike az első négy legeredményesebbnek észlelt kompetencia körébe tartozik. Képzési területenként a legjelentősebb különbségek pedig a következőkben találhatóak: a hallgatók tanulástámogatásában, az újonnan érkező hallgatók szocializációjának segítésében, az online tanulási környezetek tervezésében, kivitelezésében, valamint az új módszerek kipróbálásában, megosztásában, melyek mindegyike kötődik a tanulásközpontú megközelítés új feladataihoz. Az 
alábbiakban a képzési területi sajátosságokra legszenzitívebb kompetenciaterületeket részleteiben is elemezzük (4. táblázat).

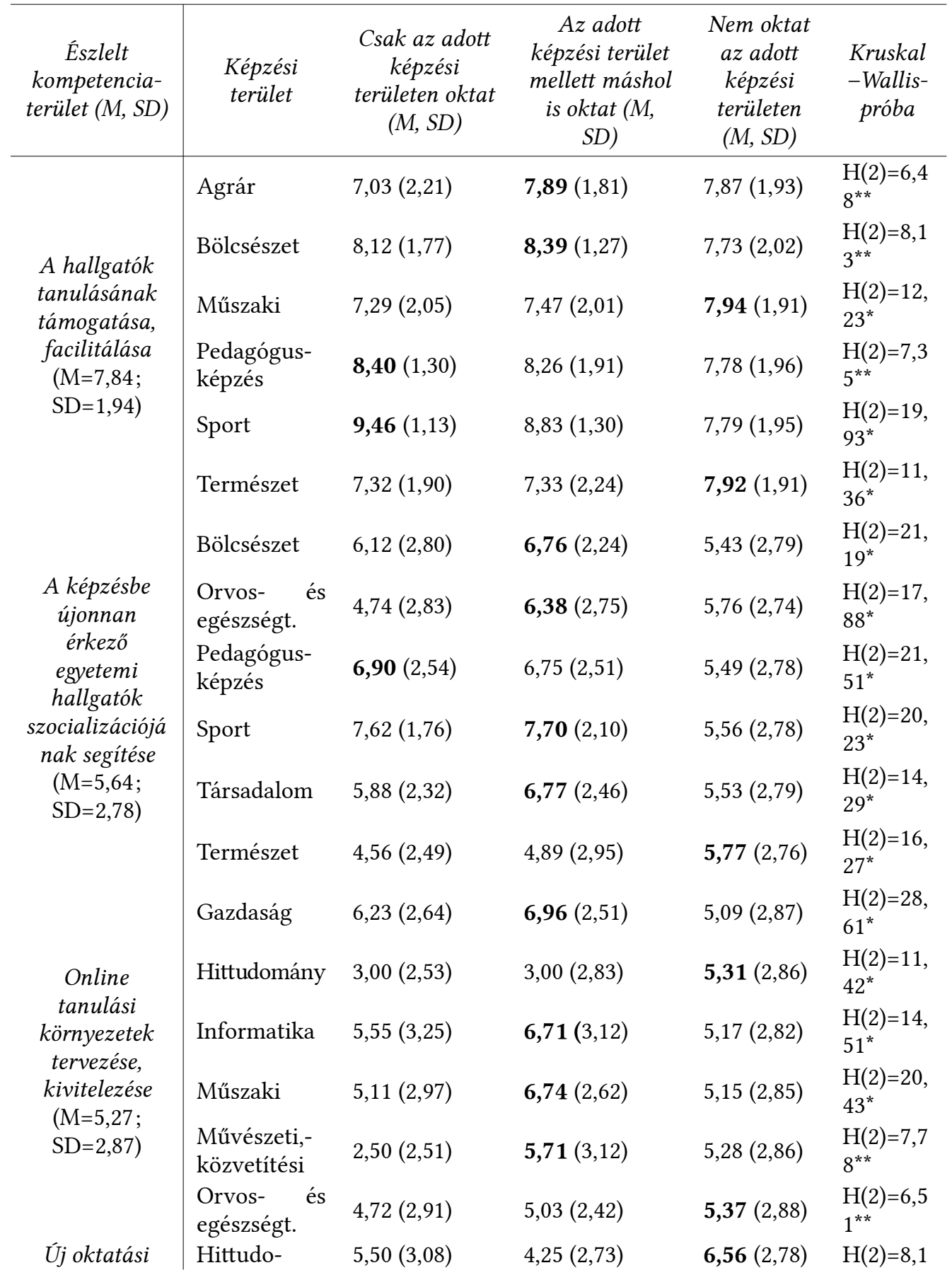


Pedagógusképzés • 18(46), 2019/1-2.

\begin{tabular}{|c|c|c|c|c|c|}
\hline \multirow{5}{*}{$\begin{array}{c}\text { módszerek } \\
\text { kipróbálása, } \\
\text { megosztása } \\
(\mathrm{M}=6,53 ; \\
\mathrm{SD}=2,79)\end{array}$} & \multicolumn{4}{|l|}{ mány } & $0^{* *}$ \\
\hline & Informatika & $5,50(2,86)$ & 7,06 $(2,94)$ & $6,54(2,77)$ & $\begin{array}{l}\mathrm{H}(2)=7,8 \\
7^{* *}\end{array}$ \\
\hline & $\begin{array}{l}\text { Művészeti,- } \\
\text { közvetítési }\end{array}$ & $7,00(2,98)$ & $\mathbf{8 , 2 1}(2,52)$ & $6,50(2,79)$ & $\begin{array}{l}\mathrm{H}(2)=7,2 \\
1^{* *}\end{array}$ \\
\hline & $\begin{array}{l}\text { Pedagógus- } \\
\text { képzés }\end{array}$ & $7,93(1,89)$ & $7,48(2,64)$ & $6,39(2,80)$ & $\begin{array}{l}H(2)=20, \\
96^{*}\end{array}$ \\
\hline & Természet & $5,58(2,77)$ & $6,17(2,58)$ & $\mathbf{6 , 6 2}(2,79)$ & $\begin{array}{l}\mathrm{H}(2)=10, \\
48^{*}\end{array}$ \\
\hline
\end{tabular}

4. táblázat: A több képzési terület mentén eltérően észlelt oktatói kompetenciák átlagai, szórásai és különbségük. (10-fokú skála, Szignifikancia: ${ }^{*} \mathrm{p}<0,05,{ }^{* *} \mathrm{p}<0,01(\mathrm{~N}=960)$.

Az észlelt oktatói kompetenciák képzésterületenkénti összehasonlításának leglényegesebb eredménye, hogy az oktatók többnyire akkor érzékelik jobbnak a kompetenciáikat, ha nemcsak egy adott képzési területen tanítanak, hanem több szak-, illetve tudományterületen is. Ez alól tipikus kivétel a pedagógusképzés és a sporttudomány, ahol a csak az adott szakterületen tanítók észlelt kompetenciájának értéke magasabb, mint amikor mellette más képzési területen is tanítanak. Mindez magyarázható a képzési területek közvetlen pedagógiai kapcsolataival is. A hittudomány területén előforduló hasonló mintázat értelmezése kapcsán ugyanakkor ez nem mondható el, a kapott eredményeket viszont a nagyon kis elemszám miatt óvatosan kell kezelnünk.

A hallgatók tanulásának támogatása kompetencia kevésbé jellemző a kemény tudományok képviselőire, mint például az agrár-, műszaki és természettudomány oktatóira, viszont a bölcsészeti, pedagógusképzési és sporttudományi területen erősebb összevetve azokkal, akik ilyen területen nem tanítanak. A szintén tanulás-központúsághoz kötődő kompetenciaterület, az újonnan érkező hallgatók szocializációjának segítése kapcsán pedig azt látjuk, hogy a több képzési területen való tanítás különösen pozitívan befolyásolja az észlelt kompetenciát. Az orvos- és egészségtudomány, valamint a társadalomtudomány oktatói is akkor észlelik legpozitívabbnak a kompetenciáikat, ha az adott képzési terület mellett máshol is tanítanak. A kemény tudományok képviselői itt is alacsonyabbra értékelik a kompetenciáikat, akár a hallgatók tanulástámogatása kapcsán: a csak orvos- és egészségtudomány területén oktatókra, valamint a természettudományi képzésben tanítókra is kevésbé jellemző ez a kompetencia.

Az online tanulási környezetek tervezése különösen erős a gazdasági, informatikai, műszaki területen oktatók körében, főként, ha még más képzési területeken is tanítanak. Ezzel szemben az orvos- és egészségtudományi, valamint a hittudomá- 
nyi terület oktatói ezt a kompetenciaterületet alacsonyabb szintűnek észlelik. Azaz ezen a kompetenciaterületen a kemény- és puha-tudományok közti tipikus különbségek nem észlelhetőek, a kemény tudományterületek képviselői jobbnak és kevésbé jónak is észlelik a kompetenciáikat. Az új módszerek kipróbálását, megosztását is eltérően észlelik az egyes képzési területek oktatói: a pedagógusképzés, a művészeti- és művészetközvetítési képzési terület, valamint az informatika mellett mást is tanító oktatók eredményesebbnek tartják magukat. Míg a hittudomány és a természettudomány képviselői kevésbé jónak észlelik ezt a kompetenciaterületüket.

\section{Az oktatói kompetenciák észlelt eredményessége a tanítási tapasztalatok fényében}

Lényeges összefüggés, hogy éppen azok a kompetenciaterületek, ahol a képzési területek szerint nagyobb különbségek vannak az oktatók közt, azok nem szenzitívek a tanítási tapasztalat növekedésére - ami különösen meghatározó, hiszen ezek a területek kifejezetten a felsőoktatás újfajta feladataihoz kapcsolódnak (4. táblázat). Ez alól a hallgatók tanulásának támogatása kivétel, ahol a képzési terület mellett számít a tanítási tapasztalat is. A 13 kompetenciaterület közül 8 változik a tanítási tapasztalat növekedésével (2. ábra). 


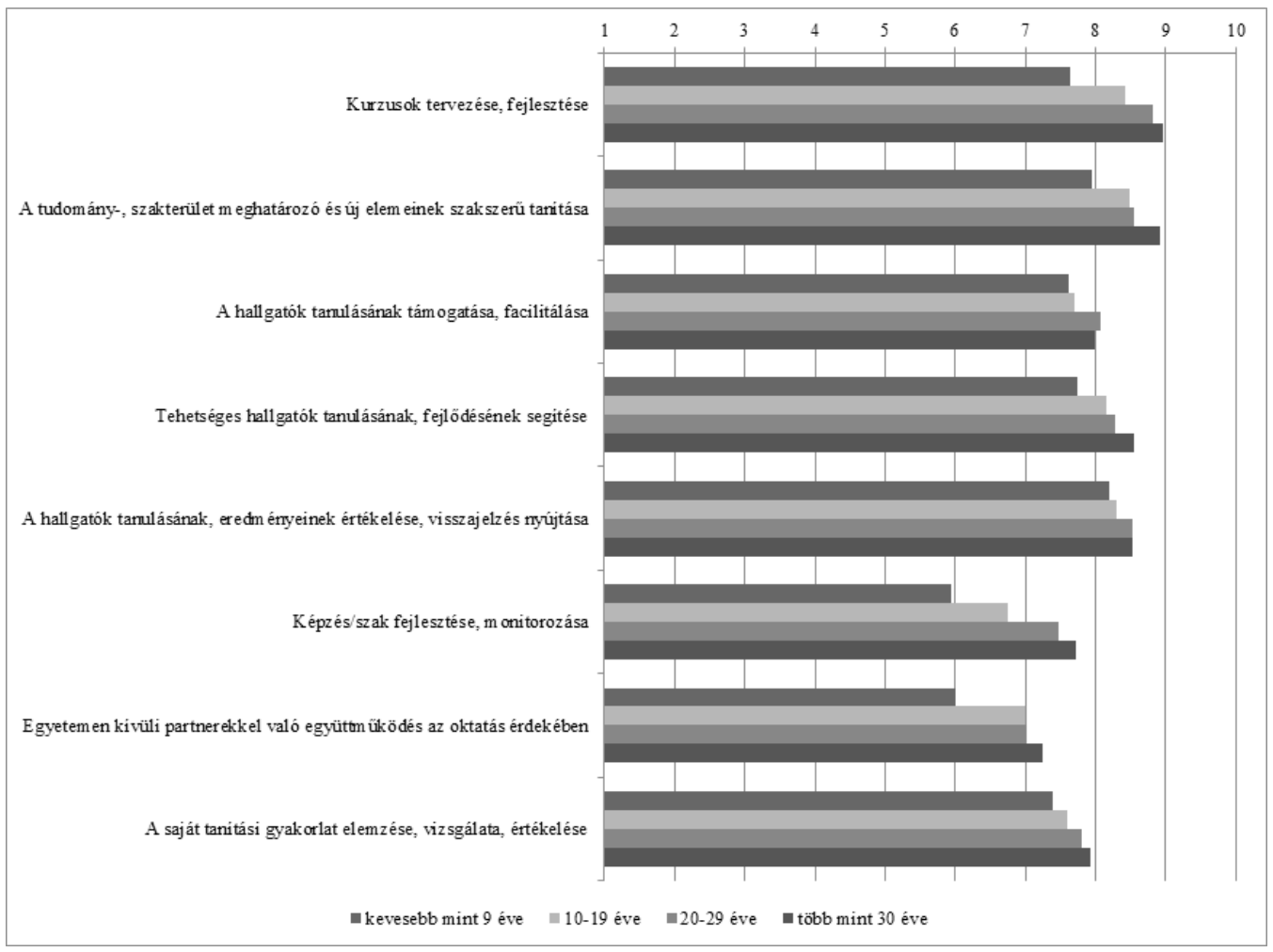

2. ábra: Az oktatók azon észlelt kompetenciaterületei, amelyek a tanítási tapasztalattal szignifikánsan változnak $(\mathrm{N}=960)$

Szignifikáns különbségeket tehát egyfelől a hallgatók tanulástámogatása terén találtunk $(\mathrm{H}(3)=12,50 \mathrm{p}<0,01)$, bár itt nem beszélhetünk ugrásszerű, nagymértékű változásokról. Másfelől a legtöbb különbséget a hagyományosan is lényeges felsőoktatási tevékenységekben tapasztaltunk, azaz a tudományterületek új elemeinek tanítása $(\mathrm{H}(3)=58,43 \mathrm{p}<0,01)$, a kurzusok tervezése $(\mathrm{H}(3)=87,90 \mathrm{p}<0,01)$, a tehetséggondozás $(\mathrm{H}(3)=29,38 \mathrm{p}<0,01)$, a hallgatók tanulásának, eredményeinek értékelése $(H(3)=11,19 \mathrm{p}<0,05)$ terén. A legjelentősebb változások a kezdő/első oktatói időszak (1-9 év tanítási tapasztalat) után következnek be, de alapvető tendencia, hogy a tanítási tapasztalattal a kompetenciaérzet fokozatosan nő. Ez alól csak a hallgatók tanulásának támogatása kompetenciaterület kivétel, ahol a 20-29 éve tanítók érzik magukat a legkompetensebbeknek, és ebben az esetben az ugrásszerü kompetencianövekedés is inkább a második, nem pedig a kezdő időszak után jelenik meg. További kivétel az értékelés kompetenciaterülete, aminek megítélése 20 év után már nem változik jelentősen. Az oktatói kompetenciák harmadik cso- 
portja, ahol jelentős különbségeket találtunk, olyan tevékenységekhez kapcsolódik, amelyek részben már szervezeti, tanszéki szintű feladatként jelennek meg. Jellemző lehet, hogy az oktatók ezekbe a feladatokba aktívan, irányító szerepben csak a pályájuk későbbi szakaszában vonódnak be: ilyen például a képzésfejlesztés $(\mathrm{H}(3)=62,70 \mathrm{p}<0,01)$ és az egyetemen kívüli partnerekkel való együttmüködés $(\mathrm{H}(3)=25,64 \mathrm{p}<0,01)$. Jól látszik az is, hogy ezeknél a kompetenciaterületeknél már nem csak az első 10 év után van egy ugrásszerủ változás, hanem a képzésfejlesztésben 20 év után, a külső partnerekkel való együttműködésben pedig 30 év után. A szakmai fejlődéshez kötődő kompetenciaterületek közül pedig a saját tanítási gyakorlat elemzése, értékelése az, ami a tanítási tapasztalatokkal kisebb mértékben, de fokozatosan nő $(\mathrm{H}(3)=16,24 \mathrm{p}<0,01)$.

\section{Az eredmények értékelése}

Mivel a felsőoktatásban is egyre nagyobb figyelmet kap a tanítás minősége, fejlesztése, előtérbe kerül az oktatók szakmai fejlődésének és tanulásának támogatása. Ehhez pedig lényeges kiindulópont lehet, hogy az oktatók hogyan értelmezik az oktatási kompetenciákat, milyen területeken látják eredményesnek, kevésbé eredményesnek magukat. E kutatás éppen ennek feltárása vállalkozott a hazai felsőoktatási kontextusban.

A kompetenciák értelmezésében nagy jelentősége van a tanulásközpontú megközelítés megjelenésének, erősödésének, hiszen ez növelheti a hallgatók tanulási eredményességét, a tanítás minőségét a felsőoktatásban. A tanulásközpontú megközelítés jelenti a tanulástámogatásra, a minden hallgatói csoport bevonására, a komplex tanulási környezetekre, a tanulási eredményekre figyelést, csakúgy, mint az oktatók szakmai fejlődésének és tanulásának felértékelődését. Az eredmények alapján azt látjuk, hogy a tanulásközpontú megközelítés bizonyos elemei fontossá válnak az oktatói gondolkodásban: egyes területeken erősebben, mint a tanulástámogatás vagy a szakmai fejlődés és tanulás kapcsán, más területeken viszont kevésbé, mint a minden hallgatói csoport támogatása vagy a tanulási környezetek fejlesztése.

A legfontosabb oktatói kompetenciák közt szerepelnek a kurzustervezéssel, hallgatói értékeléssel, az új tartalmak tanításával és a tanulástámogatással kapcsolatos területek, amelyek a tervezés, tanulásszervezés, értékelés alaptevékenységeinek hármasát mutatják. Ezek közül az alapfeladatok közül ugyanakkor csak a hallgatók tanulásának támogatása, facilitálása kötődik egyértelműen a tanulás- 
központú megközelítéshez, viszont ez a terület bekerül a legfontosabb kompetenciaterületek közé. Tovább árnyalja a képet, hogy az oktatók a kurzusok tervezése, fejlesztése és a hallgatók tanulásának, eredményének értékelése esetében is kifejezetten elégedettek a kompetenciáikkal. Az oktatók közül ráadásul a kurzusok tervezése, fejlesztése kapcsán érzik legtöbben, hogy ebben eredményesebbek, mint amennyire fontosnak tartják, és itt van a legkevesebb olyan oktató is, aki fontosabbnak tartja ezt a kompetenciaterületet, mint amennyire jellemzőnek magára nézve. Mindez azt jelenti, hogy a tervezés és értékelés területén nagyfokú az oktatói elégedettség, nem látszik, hogy a szakmai fejlődés szempontjából prioritásként gondolnának ezekre a területekre. Ez valószínủleg összefügg azzal, hogy ezeken a területeken nem erősödött meg a tanulásközpontú és a tanulási eredmények alapú megközelítés, ami egybehangzik a korábbi hazai kutatási eredményekkel (lásd Vámos, 2011; Soreco Research, 2014 idézi Berács és mtsai, 2015).

A tanulásközpontú megközelítés azon elemei, amelyek a minden hallgatói csoport támogatásához és a tanulási környezetek fejlesztéséhez kötődnek kevéssé erősek az oktatók kompetenciákról való gondolkodásában. Meglepő eredmény, hogy az oktatók a tehetséges hallgatók segitését minden egyéb oktatási tevékenységnél és kompetenciánál fontosabbra értékelik, ezáltal messze elszakad fontossága a képzésbe újonnan érkező hallgatói csoportok támogatásától, amelyek inkább a kevéssé fontos és az oktatókra kevéssé jellemző kompetenciák körébe tartoznak. A tehetséges hallgatók segítésének ilyen mértékű fontossága, és elszakadása a többi hallgatói csoport támogatásától pedig éppen szembe megy a minden hallgató támogatására kiterjedő tanulásközpontú megközelítéssel. Ugyanakkor az újonnan érkező hallgatók tanulásának támogatása és a tehetséges hallgatók segítése esetében az oktatók mintegy fele érzékeli fontosnak, de magára nézve kevésbé jellemzőnek az adott kompetenciaterületet, ami lényeges ösztönzője lehet az e területeken elinduló szakmai fejlődésnek: akár a tehetséggondozás tömegoktatásbeli gyakorlatának újragondolásáról van szó, akár új feladatok megerősödéséről. Az online tanulási környezetek tervezése ugyan a sereghajtó a kompetenciák fontossági sorrendjében, de az oktatók fele ebben az esetben is fontosabbnak értékeli a kompetenciát, mint amennyire magára jellemzőnek, ami egyfajta kiindulópontja lehet a változásoknak. Összességében az oktatói vélekedések alapján e területnél merül fel leginkább annak kérdése, hogy bár a technológiai változások új kihívásokat és feladatokat hoznak a felsőoktatás számára, ez mennyiben jelenti az oktatói kompetenciák bővülésének szükségességét. 
A szakmai fejlődéshez és tanuláshoz tartozó kompetenciaterületeket nem egységesen ítélik meg az oktatók. Alapvetően a kollégákkal való együttmüködést és a saját tanitási gyakorlat elemzését, vizsgálatát fontosnak tartják, s különösen a kollégákkal való együttműködés terén a kompetenciáikat igen jónak is látják. Ugyanakkor az oktatás fejlesztése és a szakmai fejlődés szempontjából is jelentős új oktatási módszerek kipróbálását, megosztását vagy az egyetemen kívüli partnerekkel való együttmúködést se különösen fontosnak, se különösen jellemzőnek nem tartják magukra nézve. Pedig a korábbi vizsgálatok alapján úgy tűnt, hogy a módszertani megújulásra, új tanulásszervezési megoldásokra elég nyitottak az oktatók (Vámos, 2011; Soreco Research, 2014 idézi Berács és mtsai, 2015). E terület kevésbé pozitív megítélése meglepő, és sajnos összefügghet azzal is, hogy az érthetőség miatt, példaként megadott projekt és tükrözött osztályterem, azt hívta elő az oktatókból, hogy itt nagyobb léptékủ módszertani újításokról van szó. A kollegiális együttmüködés kompetenciájának ilyen mértékű pozitív értékelése pedig veszélyt is rejthet magában, hiszen az együttműködés különböző szintjei más mértékben erősíthetik a tanulásközpontú megközelítést (például Little, 1990; Doppenberg, 2012), a korábbi eredmények pedig éppen azt mutatják, hogy a tanuló szakmai közösségekként megjelenő együttmüködés ritka (Tókos - Kovács, 2015).

Összességében tehát az oktatói kompetenciák közül a „hagyományosabb” alapfeladatok a fontosabbak, és ebben érzik az oktatók magukat eredményesebbnek is; az olyan új feladatok, mint az újonnan érkező hallgatók támogatása, képzésfejlesztés, online tanulási környezetek stb. esetében viszont kevésbé fontosnak és magukat kevésbé eredményesnek ítélik. Ugyanakkor egyfajta ösztönző lehet a változásokra, hogy ezeken a területeken megközelítőleg az oktatók fele fontosabbnak véli az adott területet, mint amennyire eredményesnek érzi magát.

Az oktatói kompetenciák differenciált képének felrajzolásához, és az erre építhető lehetséges beavatkozási pontok azonosításához, a második kutatási kérdésre válaszolva megvizsgáltuk, hogy a képzési területek és a tanítási tapasztalatok hogyan alakítják az oktatói vélekedéseket. Az eredmények alapján a legfóbb megállapításaink a következők:

1. az egyes kompetenciaterületek észlelt eredményessége a képzési területek, vagy a tanítási tapasztalatok fényében változik;

2. a tanulásközpontú megközelítés megjelenéséhez kötődő kompetenciák inkább a képzési területek mentén változnak; míg a hagyományosabb, nem 
feltétlenül a tanulásközpontú megközelítést erősítő kompetenciaterületek a tanítási tapasztalatok mentén, végül

3. egyedül a hallgatók tanulásának támogatása, facilitálása kompetencia az, amely szenzitív a képzési területek és a tanítási tapasztalatok változására is.

A képzési területek tehát leginkább a tanulásközpontú megközelítést erősítő kompetenciák kapcsán válnak fontossá. A hallgatók tanulástámogatása, az újonnan érkező hallgatók szocializációjának segítése esetében visszaköszönnek a nemzetközi kutatások eredményei (Lueddeke, 2003; Lindblom-Ylänne és mtsai, 2006; Stes - Van Petegem, 2014; Kálmán és mtsai, 2019): e kompetenciaterületek esetében is a puha tudományok oktatói (például bölcsészet, pedagógusképzés) eredményesebbnek észlelik magukat a „kemény” tudományok képviselőinél (például természettudományi, agrár). Ugyanakkor az online tanulási környezetek tervezésében, valamint az új módszerek kipróbálásában, megosztásában már differenciáltabb a kép. A műszaki és informatikai képzés oktatói is eredményesnek érzik magukat, csakúgy, mint a puha tudományok képviselői - különösen pedig akkor, ha nem csak egy képzési területen dolgoznak. Az eredmények megerősítik a képzési területek eltérő oktatási sajátosságait, a tipológiák ma már túlzóan leegyszerüsítő voltát. Összességében pedig kiemelendő a több képzési területen való tanítás pozitív hatása a kompetenciák eredményességének érzékelésére, még a kemény tudományok esetében is. Ugyanakkor meg kell jegyezni, hogy a természettudományi terület oktatói azok, akik leginkább és legkonzekvensebben kevésbé jónak érzik ezeket a kompetenciáikat.

A hagyományosabb oktatói kompetenciaterületeken számít jobban a tanítási évek száma (például a kurzusok tervezése; a tudomány-, szakterület új eredményeinek tanitása; a tehetséges hallgatók tanulásának, fejlődésének segitése). Jellemzően az első kezdeti időszak ( 9 év alatti tanítási tapasztalat) után látható egy ugrásszerü növekedés, bár ez az emelkedés több terület esetében inkább 20 év után következik be (például a hallgatók tanulásának támogatása; a hallgatók tanulásának, eredményeinek értékelése; képzésfejlesztés). Mindez jelezheti azt, hogy ezeken a területeken működik a szakmai szocializáció, a gyakorlatközösségekben való informális tanulás, ami különösen az első időszakban jelentős hatású. Ugyanakkor bizonyos kompetenciaterületek - többek közt az inkább vezetői feladatokhoz is köthető képzésfejlesztés, egyetemen kívüli partnerekkel való együttmüködés - fejlődése későbbi időszakokban is meghatározó. 
A tanulásközpontú megközelítés szempontjából kiemelten érdemes foglalkozni a hallgatók tanulásának támogatása kompetenciaterülettel, amely inkább a puha, mint a kemény tudományterületek oktatói körében erősebb. A tanítási tapasztalatok mentén pedig nem a szokásos, kezdeti időszak utáni kompetenciaérzet növekedését mutatják, hanem 20 év tanítási tapasztalat után találtunk egy ugrásszerü növekedést. Mindez azt jelenti, hogy az oktatók szakmai fejlődése és tanulása során a tanulásközpontú megközelítés lassabban erősödik meg. A szakmai fejlődés támogatásának, a beavatkozásoknak pedig nemcsak a kezdő időszakban lehet jelentősége, hiszen e kompetenciaterület eredményességének érzékelése kifejezetten a pálya későbbi időszakában erősödik fel, ráadásul számos, a tanulásközpontú megközelítéshez szorosan kapcsolódó kompetenciaterület alakulása szempontjából nem is játszik szerepet a tanítási tapasztalat.

Végül a kutatás korlátai közt számba kell venni, hogy az eredmények egy önkitöltős kérdőíves adatfelvételből származnak, s hogy annak ellenére, hogy az oktatói kompetenciákat igyekeztünk a hazai kontextusra adaptálni, bizonyos területek értelmezése így is problémát jelenthetett az oktatók számára. Bár a kompetenciák megfogalmazása részben idegenül hathatott, olykor nehezebben értelmezhető lehetett, a kompetenciaterületek előzetes kialakítását továbbra is hasznosnak tartjuk, mert így az oktatók a kompetenciaterületek szélesebb köréről tudtak véleményt formálni. Éppen ezért a további kutatásokban érdemes majd egy-egy kompetenciaterületet mélyebb értelmezésére vállalkozni (például a hallgatók tanulásának támogatása vagy a hallgatók tanulásának, eredményeinek értékelése).

\section{A kutatás gyakorlati implikációi}

A kutatásban fejlesztett oktatói kompetenciaterületek bár nem törekednek egy teljes és koherens keretrendszer megteremtésére, az eredmények alapján úgy tủnik, jól tudták megragadni a hazai felsőoktatás tipikus tevékenységeire épülő kompetenciaterületeket. Így azt gondoljuk, hogy használható e lista az oktatók önreflexiójának és szakmai tanulásuk megtervezésének támogatásához. Ugyanakkor a kompetenciák leírásában érdemes a tervezés és értékelés területének további részletezése annak érdekében, hogy a tanulásközpontú megközelítés sajátosságai, illetve hiányai egyértelműen kirajzolódjanak.

A kutatás eredményei továbbá felhívják a figyelmet az oktatók szakmai fejlődésének és tanulásának támogatásakor fellépő nehézségekre, kiaknázható lehető- 
ségekre. Ilyen kiaknázható lehetőségként a következőket látjuk az eredményeink alapján:

1. Az oktatók a hallgatók tanulásának támogatását, facilitálását a legfontosabb kompetenciaterületek közt tartják számon, tehát az ezen a területen való fejlődés érdekében nyitottak lehetnek a tanulásra.

2. A tanulásközpontú megközelítés szempontjából igen releváns kompetenciáikat jobbnak értékelik azok az oktatók, akik több képzési területen is tanítanak, tehát ennek tudatosítása, kiaknázása, elősegítése előnyös lehet a szakmai fejlödés és tanulás támogatása során.

3. Az eredményeink továbbá azt mutatják, hogy a tanulásközpontú megközelítés erősödését hozó kompetenciaterületek fejlődése nem szenzitív a tanítási tapasztalatokra, ráadásul a többi kompetenciaterületen is az eredményesség növekedésének érzése nemcsak a kezdeti időszakban, hanem később is ugrásszerű változásokat mutat. Mindez pedig óvatosságra int annak kapcsán, hogy a felsőoktatásban a szakmai fejlődés és tanulás támogatásának elsődleges célcsoportjai a kezdő oktatók legyenek; és inkább az oktatói karrier hosszabb időszakára fókuszált támogatás mellett teszi le a voksot.

Végül az oktatók szakmai fejlődésének és tanulásának támogatása során problémát jelenthet a „túlzó elégedettség” is. Úgy tűnik, hogy az oktatók bizonyos kompetenciaterületekkel igencsak elégedettek, sőt talán még kritikusak is, hiszen kevésbé tartják fontosnak, mint amennyire jellemzi őket. Ezek közé tartozik elsősorban a kurzusok tervezése, fejlesztése; a kollégákkal való együttműködés az oktatásban; valamint a hallgatók tanulásának, eredményeinek értékelése. E területek támogatása önmagától nem fog vonzóvá válni az oktatók számára, így különös figyelmet kell fordítani e kompetenciaterületek komplexitásának tudatosítására. 


\section{Irodalom}

Bandura, A. (1993): Perceived Self-Efficacy in Cognitive Development and Functioning. Educational Psychologist, 28. évf., 2. sz. 117-148.

Becher, T. (1994): The significance of Disciplinary Differences. Studies in Higher Education, 19. évf., 2. sz. 151-161.

Berács József - Derényi András - Kováts Gergely - Polónyi István - Temesi József (2015): Magyar felsőoktatás 2014. Stratégiai helyzetértékelés. Budapesti Corvinus Egyetem, Nemzetközi Felsőoktatási Kutatások Központja, Budapest.

Biggs, J. - Tang, C. (2003): Teaching for quality learning at university. McGrawHill International, Maidenhead.

Biglan, A. (1973): The characteristics of subject matter in different academic areas. Fournal of Applied Psychology, 57. évf., 3. sz. 195-203. http://dx.doi.org/ 10.1037/h0 034 701 Letöltés ideje: 2019. 07. 05.

Borg, M. (2001): Key concepts in ELT. Teachers' beliefs. ELT Journal, 55. évf., 2. sz. 186-188. https://doi.org/10.1093/elt/55.2.186 Letöltés ideje: 2019. 07. 05.

Chalmers, D. - Cummings, R. - Elliott, S. - Stoney, S. - Tucker, B. - Wicking, R. de St Jorre, T. (2014): Australian University Teaching Criteria and Standards Project, Final Report 2014. Office for Learning and Teaching, Sydney. http:// uniteachingcriteria.edu.au/wp-content/uploads/2013/11/Draft-SP12-2335Project-Final-Report-21-July-2014.pdf Letöltés ideje: 2019. 07. 05.

Daniels, J. (2016): Professional learning in higher education: making good practice relevant, International fournal for Academic Development, 22. évf., 2. sz. 1-12. https://doi.org/10.1080/1360 144X.2016.1261352 Letöltés ideje: 2019. 07. 05.

de Vries, S. - van de Grift, W. J.C.M. - Jansen, E. P.W.A. (2014): How teachers' beliefs about learning and teaching relate to their continuing professional development, Teachers and Teaching: theory and practice, 20. évf., 3. sz. 338-357. https://doi.org/10.1080/13540 602.2013.848521 Letöltés ideje: 2019. 07. 05.

Doppenberg, J. J. - den Brok, P. J. - Bakx A. W. E. A. (2012): Collaborative teacher learning across foci of collaboration: Perceived activities and outcomes. Teaching and Teacher Education, 28. évf., 6. sz. 899-910.

Falus Iván (2006): A tanári tevékenység és a pedagógusképzés új útjai. Gondolat Kiadó, Budapest.

Falus Iván (szerk., 2007): A tanárrá válás folyamata. Gondolat Kiadó, Budapest.

Falus Iván (szerk., 2015): A pedagógusképzők kompetenciái. Líceum Kiadó, Eger.

Ferman, T. (2002): Academic professional development practice: What lecturers find valuable. International fournal for Academic Development, 7. évf., 2. sz. 
146-158. https://doi.org/10.1080/1360144032000071305 Letöltés ideje: 2019. 07. 05.

Harden, R. M. - Crosby, J. (2000): AMEE Guide No 20: The good teacher is more than a lecturer - the twelve roles of the teacher. Medical Teacher, 22. évf., 4. sz. 334-347.

Hénard, F. - Roseveare, D. (2012): Fostering Quality Teaching in Higher Education: Policies and Practices. OECD IMHE, Paris.

http://www.oecd.org/edu/imhe/QT\%20policies\%20and\%20practices.pdf Letöltés ideje: 2019. 07. 05.

Kálmán Orsolya (2009): A hallgatók tanulási sajátosságai és ezek változása. Doktori értekezés. ELTE PPK Neveléstudományi Doktori Iskola.

Kálmán Orsolya (2013a): A pedagógusjelöltek és pedagógusok nézetei - hazai kutatások nemzetközi kontextusban. In: Kotschy Beáta (szerk.): Új utak a pedagóguskutatásban: Tanulmánykötet Falus Iván tiszteletére. Líceum Kiadó, Eger. 81104.

Kálmán Orsolya (2013b): Tanulástámogatás a felsőoktatásban. Felsőoktatási Múhely, 7. évf., 2. sz. 15-22.

Kálmán Orsolya (2016): Az oktatók elképzelései a szakmai fejlődésükről, pedagógiai kompetenciáikról és a tanításukról. In: Garai Imre - Vincze Beatrix - Szabó Z. A. (szerk.): Hiteles pedagógia. Tanulmányok Golnhofer Erzsébet tiszteletére. ELTE Eötvös Kiadó, Budapest. 46-58.

Kálmán Orsolya (2018): Az oktatók szakmai fejlődésének és tanulásának megközelítései a felsőoktatásban. In: Fehérvári Anikó (szerk.): A Borsszem fankótól Bolognáig. Neveléstudományi tanulmányok. ELTE PPK - L’Harmattan, Budapest. 218-236.

Kálmán, O. - Tynjälä, P. - Skaniakos, T. (2019): Patterns of university teachers' approaches to teaching, professional development and perceived departmental cultures, Teaching in Higher Education, https://doi.org/10.1080/13562517.2019.1586667 Letöltés ideje: 2019. 07. 05.

Kember, D. - Kwan, K. (2000): Lecturers' approaches to teaching and their relationship to conceptions of good teaching. Instructional Science, 28. évf., 5. sz. 469-490. https://doi.org/10.1023/A:1 026569608656 Letöltés ideje: 2019. 07. 05.

Koltói Lilla (2017): Tanítójelöltek kompetenciaérzésének tanulmányi és társas meghatározói. Pedagógusképzés, 16(44). évf., 1-4. sz. 33-55.

Kovács Zsuzsa - Kereszty Orsolya (2016): Az oktatási feladatokról és szerepekrôl való gondolkodás a hazai doktoranduszok körében. Neveléstudomány, 4. évf., 4. sz. 5-19._https://doi.org/10.21549/NTNY.16.2016.4.1 Letöltés ideje: 2019. 07. 05. 
Lindblom-Ylänne, S. - Trigwell, K. - Nevgi, A. - Ashwin, P. (2006): How approaches to teaching are affected by discipline and teaching context. Studies in Higher Education, 31. évf., 3. sz. 285-298.

https://doi.org/10.1080/0 3075070600680539 Letöltés ideje: 2019. 07. 05.

Little, J. W. (1990): The Persistence of Privacy: Autonomy and Initiative in Teachers' Professional Relations. Teachers College Record, 91. évf., 4. sz. 509-536.

Lueddeke, G. R. (2003): Professionalising Teaching Practice in Higher Education: A study of disciplinary variation and 'teaching-scholarship'. Studies in Higher Education, 28. évf., 2. sz. 213-228. https://doi.org/ 10.1080/0307507 032000058082 Letöltés ideje: 2019. 07. 05.

Lukács István - Derényi András (szerk., 2017): Kézikönyv a képzési programok tanulási eredményeken alapuló fejlesztéséhez, felülvizsgálatához. Oktatási Hivatal, Budapest.

Melief, K. - van Rijswijk, M. - Tigchelaar, A. (2012-2013): A holland pedagógusképzők szakmai sztenderdjeinek 2012. évi átdolgozott változatáról. Pedagógusképzés, 10-11(39-40). évf., összevont szám 149-182.

Ödalen, J. - Brommesson, G. - Erlingsson, G. - Schaffer, J. K. - Fogelgren, M. (2019): Teaching university teachers to become better teachers: the effects of pedagogical training courses at six Swedish universities. Higher Education Research \& Development, 38. évf., 2. sz. 339-353.

https://doi.org/10.1080/07 294360.2018.1512955 Letöltés ideje: 2019. 07.05.

Prosser M. - Trigwell, K. - Taylor, P. (1994): A phenomenographic study of academics' conceptions of science learning and teaching. Learning and Instruction, 4. évf., 3. sz. 217-231. https://doi.org/10.1016/0959-4752(94)90 024-8 Letöltés ideje: 2019. 07. 05.

Rapos Nóra (2016): A támogatás értelmezése a személyes szakmai életúton. In: Vámos Ágnes (szerk.): Tanuló pedagógusok és az iskola szakmai tőkéje. ELTE Eötvös Kiadó, Budapest. 79-102. 


\section{University Lecturers' Teaching Competencies from the Lecturers' Perspective}

This study aims to explore how Hungarian university lecturers interpret teaching competencies and perceive the importance and effectiveness of their own competencies. The study establishes that their perceptions vary depending on their study fields and teaching experience. The research findings also reveal that certain elements of the student-centred approach (e. g. the facilitation of students' learning) have gained importance for the academics, as well as the fact that competencies closely linked to the student-centred approach correlate more with study fields than with the accumulation of teaching experience.

Keywords: teaching competencies, university lecturers' professional development and learning, higher education, study fields, teaching experience 